The Chittagong Univ. J. Sci. 41(1) : 21-38, 2019

DOI: https://doi.org/10.3329/cujs.v41i1.51913

\title{
Determinants of Drug Addiction in Slum and Non-slum Areas of Chittagong, Bangladesh
}

\author{
Md. Monirul Islam*, Md. Imam Hussain and Md. Shahidul Islam \\ Department of Statistics, University of Chittagong, Chittagong-4331, Bangladesh \\ *Correspondence author: mi.custatistics@gmail.com
}

\begin{abstract}
This research paper is a modest attempt to examine the prevalence and differentials of drug addiction in slum and non-slum areas of Chittagong, Bangladesh. The study revealed that about 53 per cent of males and 47 per cent of females were drug addicted in slum areas while in non-slum areas, the percentages of the addicted males and females are about 73 and 55 respectively. In both the areas, it was observed that the drug addicted peoples were suffering from dyspepsia, pain in lever, declining sexual ability, hepatitis, vomiting and other diseases. From the multivariate analysis, it was observed that respondent's religion, type of family, number of family members, economic status, occupation, duration of taking drugs, watching TV/LCD, reading newspaper or magazine, habit of smoking, knowledge about drugs, knowledge about the harmful effect of drugs, causes behind taking the drugs and drugs buying spots were found to be positively significant effect on drug addiction in slum areas, while in non-slum areas, respondent's religion, educational qualifications, number of family members, economic status, occupation, knowledge about drugs, watching TV/LCD, reading newspaper or magazine, suffering from diseases due to drugs, knowledge about the harmful effect of drugs, type of drugs, causes behind taking drugs, drugs buying spots and tendency to come back from
\end{abstract}


drugs were found to be positively significant effect on drug addiction. It was observed that majority of the addicted respondents use cannabis in both the areas compare to other type of drugs.

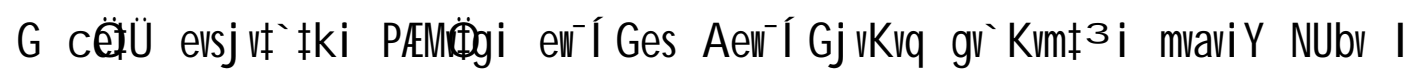

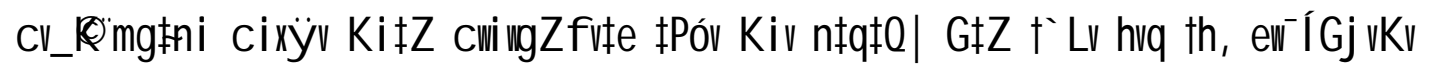

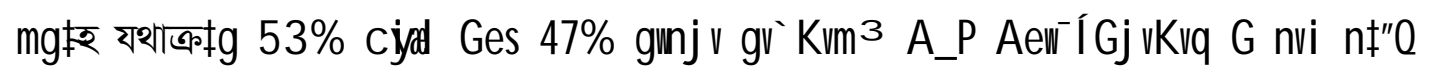

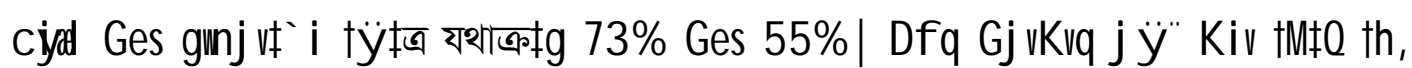

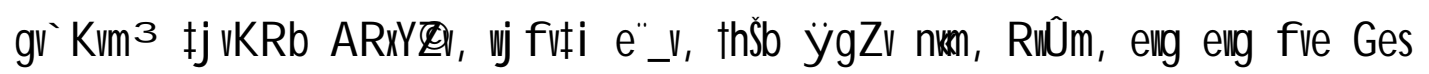

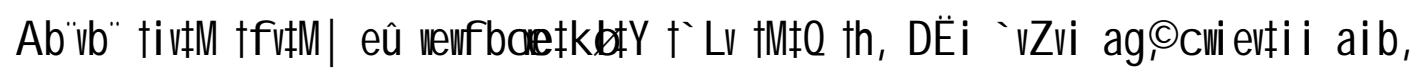
cvietti mìñl nsev̀ cl̂ evgü

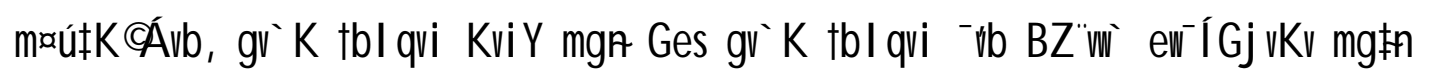

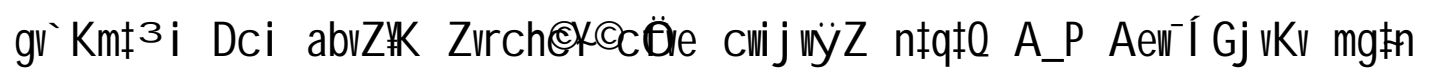

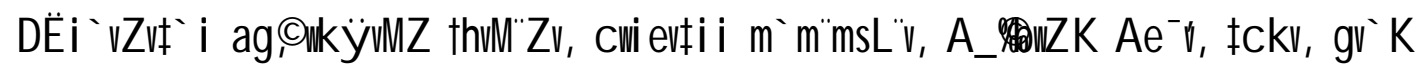

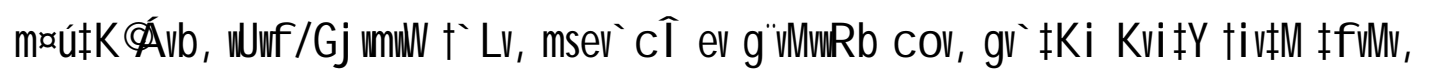

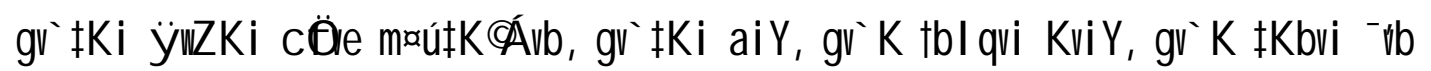

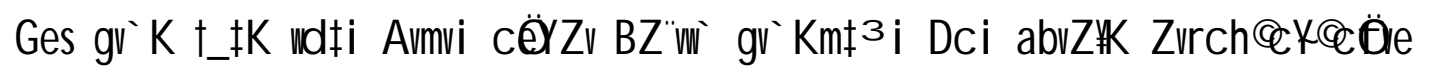

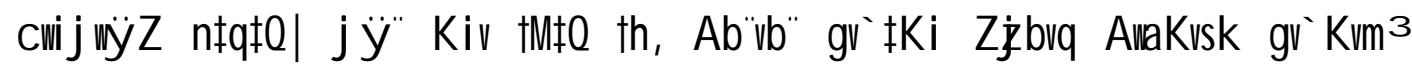
DËi `ZvDfqG Kıqf \& (cannabis) ëenv K\$ |

Keywords: Drug addiction, logistic regression analysis, Causes of drug addiction, Come back from drug addiction. 


\section{Introduction}

Drug addiction means taking heroin, opium, cocaine, marjuna, morphine, phensidyl, cannabis, yaba, wine, pathedrine etc. Some of these are taken by smoking or through injection. These drugs are used for intoxicating and stimulating effects. Drug addiction is not only a national problem but also a global problem. In most of the developing countries like Bangladesh, drug addiction creates the multifarious problems.

Drug addiction is increasing day by day in urban, rural, slum, and non-slum areas of Bangladesh [1]. It is directly or indirectly depends on various factors. Generally it depends on age, education, monthly income, professions, place of residence, family type etc. Bangladesh is a developing country. Most of the people of our country are illiterate but 51.8 per cent people are literate [2] and due to illiteracy, people have lack of knowledge of the bad effect of drugs. The illiterate peoples take easily the different type of drugs compare to literate persons.

Crime violence, poverty, unemployment, family confliction, sexual diseases, broken family, corruption, black money, invalid live together, misuses of internet, foreign channels, blue films, frustration, inadequate health care facilities, relationship between addicted friends etc. are the major problems in Bangladesh. Inflection of these complexities, the entire Bangladesh is now being affiliated by the drug abuse related problems. For technological advancement, peoples know the different type of drugs and as well as they captured the using mechanisms of it easily. In Bangladesh, patriotism, honesty, morality, ethical standard and civic sense among the peoples is going down day by day. As a result, the whole society 
24 Md. Monirul Islam, Md. Imam Hussain and Md. Shahidul Islam

becomes unhealthy. These are the harmful effect of drugs for entire society and also alarming too.

Most of the people of Bangladesh live in rural areas. Except agricultural work, very little scope is there in the rural area for economic activity for this vast majority of rural area. So, they are coming to the city or town and are looking for a work. On finding no other suitable work, they become rickshaw puller, van driver, day labor etc. Most of them are engaged in theft and hijacking or any other illegal activities. So, professionally they are addicted in different type of drugs.

In our society, drug addiction has grasped the young generation. The drug addicted people are bound to do crime to collect money. It is estimated that there are approximately 4.6 million drug abusers in Bangladesh [3].

Recently, the international drug smugglers often use Bangladesh as a transit of transmission of drug from one country to another [1]. In the above circumstances all concerned must be careful at personal and family levels against the dangerous impact of drug addiction among the youth.

However, it is essential to address to drug addiction predominantly socio-economic and demographic profile scientifically and immediately, because once their assessment data has been collected, a national strategy for effective management and prevention can be established. Such strategy may contribute for the improvement of their quality of life and be used for the prevention of further deterioration of drug addiction.

In this paper, we have tried to know the levels of overall knowledge of drugs and attitude towards drugs. In this study, we tried to identify the effect of socio- 
economic and demographic factors on drug addiction, what type of drugs are used, from where these drugs are collected and the causes behind taking drugs, the people of which area are more involved with drug addiction and drug trafficking. This study aimed to find out the tendency of the addicted people to return from this way.

\section{Data and Methodology}

The data for the present study were collected from selected slum and non-slum areas in Chittagong metropolitan area in Bangladesh during the period January to July, 2015. For data collection, a two-stage cluster sampling design was adopted. At the first stage, a sample of 5 wards (clusters) was randomly selected out of 41 wards (clusters) in Chittagong metropolitan area and from the selected wards, 7 slum areas were chosen randomly out of 21 slum areas. The total numbers of addicted persons in 7 selected slum areas are 4,896 while in non-slum areas of selected 5 wards, total number of addicted persons are 3,729 [7]. In the second stage, out of 4,896 addicted persons, 800 addicted and non-addicted respondents were randomly selected from slum areas and out of 3,729 addicted persons, 700 addicted and non-addicted respondents were randomly selected from the non-slum areas. Finally a sample of mentioned respondents were successfully interviewed in slum and non-slum areas of Chittagong metropolitan area. The field interviewing of the respondents was carried out with the help of five field workers among them two were women. They were all educated and almost all had previous experience of working as an interviewers. The interviewers were further trained and instructed to be very careful to fill up the questionnaire.

Since all selected explanatory variables are categorical, we apply the technique of logistic regression analysis to investigate the factors related to drugs, and also to 
Md. Monirul Islam, Md. Imam Hussain and Md. Shahidul Islam

identify the significant socio-economic and demographic factors on drug addiction in Chittagong metropolitan area. Besides logistic regression, the respondents were classified by demographic characters and addiction level by using chi-square test.

\section{Results and Discussion}

Table 1 display the percentage distribution of respondents who have already addicted in different type of drugs in slum and non-slum areas of Chittagong metropolitan area. The results table reveals that in slum areas, 21.2 per cent and 19.9 per cent of male and female respondents who were addicted in cannabis (which is the highest) while in non-slum areas, these figures are 24 per cent and 17 per cent respectively. The results also reveals that about 53 per cent and 47 per cent of the male and female respondents were addicted in different type of drugs in slum areas while in non-slum areas, these figures are about 73 per cent and 55 per cent respectively. The results of the another study it was observed that about 23 per cent and 12 per cent of the male and female respondents were addicted in heroin and wine in rural areas of Bangladesh [5].

Table 2 represents the percentage distribution of drug addicted respondents in both slum and non-slum areas by selected some demographic and socio-economic variables. The first panel of the table indicates that the percentages of the respondents among male, joint type of family, number of family members more than 5 , age less than 30 years, suffering from diseases due to drugs and habit of smoking of the respondents were higher than the other categories of the selected demographic variables. The results of the table show that more than 81 and 77 per cent drug addicted respondents are suffering by different types of diseases in slum 
and non-slum areas respectively. Most of the respondents (37 per cent and 32.3 per cent) in both areas suffering from dyspepsia. To test the association between drug addiction and selected independent variables, we apply $\chi^{2}$ test statistic and the value of the $\chi^{2}$ statistic indicates that there are strong positive association between selected socio-demographic variables and drug addiction.

From the last panel of the table 2 reveals that the percentages of the respondents of non-Muslim, having knowledge about drugs, low economic status, unemployment, not watching TV or LCD, no reading news paper or magazine, knowledge about the harmful effect of drugs in both slum and non-slum areas are higher than the other categories of the selected socio-economic variables and there are strong positive association between drug addiction and them. In India, it was observed that the percentages of the non-Muslim respondents who were addicted in different type of drugs were higher than the Muslims counterparts [4]. The last panel of the table 2 indicates that in slum areas, illiterate respondents were more addicted in drugs (36.1 per cent) than literate respondents while in non-slum areas, higher educated respondents were more addicted in drugs than illiterate respondents. This panel of the table also indicates that about 16 per cent of the respondents in both areas bought different types of drugs in Chittagong old railway station. About 88 and 77 per cent drug addicted respondents are wanted to comeback from this bad habit and lead to a normal life in slum and non-slum areas respectively. It was observed that there are strong positive association between the selected socio-economic variables and drug addiction. 
To assess the relative influences of the demographic and socio-economic factors on drug addiction, we undertook a logistic regression analysis. Because, drug addiction was defined by a dichotomous variable (if addicted $=1$ and not-addicted $=0$ ). From the table 2, we observed that there are strong association between the selected independent variables and drug addiction. All the variables under study are significantly associated with drug addiction levels, so to study the impact of these variables we have used all the variables in the logistic regression model. Moreover, all pre-requisite conditions of logistic regression analysis are fulfilled.

Tables 3 and 4 display the logistic regression coefficients, standard errors of regression coefficients and relative odds ratios for the respondents of drug addiction in slum and non-slum areas respectively. From the first panel of the table 3 , we observed that respondent's family type, number of family members, and habit of smoking and the second panel of the table, we also observed that respondent's religion, economic status, knowledge about drugs, occupation, duration of taking drugs, watching TV or LCD, reading news paper or magazine, knowledge about the harmful effect of drugs, causes behind taking the drugs, and drugs buying spots have a positive significant effect on drug addiction in slum areas of Chittagong metropolitan area in Bangladesh. The results of the table also indicate that sex of the respondents, types of diseases due to drugs, and tendency to come back from drugs have a negative significant effect on drug addiction.

From the results of the panel 1 of the table 4 show that respondent's number of family members, and suffering from diseases due to drugs have a positive significant effect on drug addiction and the results of the panel 2, we observed that 
respondent's religion, educational qualifications, knowledge about drugs, economic status, occupation, watching TV or LCD, reading news paper or magazine, type of drugs, causes behind taking drugs, drugs buying spots and tendency to come back from drugs were found to be positively significant effect on drug addiction in nonslum areas in Chittagong Metropolitan area. The results of the table indicates that only respondent's sex and types of diseases due to drugs have a negatively significant effect on drug addiction in non-slum areas. It is interesting that educational qualifications and type of drugs have no significant effect on drug addiction in slum area while in non-slum areas; these variables have a positively significant effect on drug addiction. The results of the tables 3 and 4 reveal that respondent's age, family type, habit of smoking, and duration of taking drugs have no significant effect on drug addiction. In some developing countries, it was observed that habit of smoking and sex of the respondents have a positive significant effects on drug addiction [6].

\section{Conclusions}

The preceding results of the study reveal that a vast majority male respondents in both slum and non-slum areas are more addicted in drugs than female respondents. It appears that the percentage of drug addiction in both the areas were found to be lower among those who are watching TV/LCD regularly compared to among those who did not. It is remarkable that in slum areas, the highest percentage of drug addiction due to close contact with friends but in non-slum areas, the highest percentage of drug addiction due to couple conflict. The main factors behind the drug addiction are habit of smoking, unemployed, rickshaw pullers/ day labors, businessmen, and low income. Most of the addicts are suffering from various 
Md. Monirul Islam, Md. Imam Hussain and Md. Shahidul Islam

harmful and chronic diseases. Among them about 37 per cent and 32 per cent respectively in slum and non-slum areas are suffering from Dyspepsia, about 22 per cent and 19 per cent from pain in liver, and about 18 percent and 17 percent lose their sexual ability. In slum areas, majority of the respondents have taken cannabis and phensidyl where as in non-slum areas, majority of the respondents have taken cannabis, heroin, and phensidyl. The results also indicate that drugs are available in Chittagong old railway station, Akber Shah Mazar, Port connecting road (Hali Shahar), Bohaddar Hat, Firoz shah lane, Madar Bari and other areas.

\section{Recommendations and Policy Implications}

The following propositions ask for special attention to get rid of drug addiction:

(i) From the study it was observed that majority of the unemployed respondents are more drug addicted so, government should adopt proper steps to overcome unemployment;

(ii) The parents should be more conscious about their responsibility and behavior; they should encourage their children to avoid bad company. In our conjugal life, we should always try to grow sacrificing mentality and cordially try to understand others behavior and attitude;

(iii) Government should strongly handle drug trafficking;

(iv) Drug trafficking is going on and maximum drugs traffickers are living in the slum areas, so, government should take quick attempt to overcome this problem; 
(v) Civil society should play effective role by campaigning against drugs. Electronic and print media plays an important role to aware the people from the bad effect of drugs;

(vi) Government and NGOs should take effective programs to ensure proper treatment and rehabilitation of drug abuser;

(vii) Parents should know the friend list of their sons and daughters to control the unwanted habits like drugs;

(viii) Parents should treated as a friend of their sons and daughters from early boyhood;

(ix) Government should take proper initiative to introduce a chapter named dangerous effect of drug addiction in the syllabus at school level.

Table 1. Percentage of respondents addicted to different type of drugs.

\begin{tabular}{|c|c|c|c|c|}
\hline \multirow[t]{2}{*}{ Type of drugs } & \multicolumn{2}{|c|}{ Slum areas } & \multicolumn{2}{|c|}{ Non-slum areas } \\
\hline & Male & Female & Male & Female \\
\hline Heroin & 4.0 & 3.6 & 11.3 & 9.6 \\
\hline Phensidyl & 10.5 & 10.1 & 12.0 & 10.3 \\
\hline Cannabis & 21.2 & 19.9 & 24.0 & 17.0 \\
\hline Wine & 7.6 & 6.2 & 8.5 & 6.1 \\
\hline Tablet & 5.4 & 3.0 & 6.4 & 5.4 \\
\hline Pethedrine & 4.7 & 4.2 & 10.5 & 7.0 \\
\hline Addicted & 53.4 & 47.0 & 72.7 & 55.4 \\
\hline Not-addicted & 46.6 & 53.0 & 27.3 & 44.6 \\
\hline Grand Total & 100.0 & 100.0 & 100.0 & 100.0 \\
\hline
\end{tabular}

Table 2. Percentage distribution of drug addicted respondents in both slum and non- slum areas of Chittagong metropolitan area according to selected variables and their categories.

\begin{tabular}{|c|l|l|l|l|}
\hline $\begin{array}{l}\text { Serial } \\
\text { Nos. }\end{array}$ & Variables & Categories & $\begin{array}{l}\text { Percentage (Slum } \\
\text { areas) } \mathrm{n}=800\end{array}$ & $\begin{array}{l}\text { Percentage (Non- } \\
\text { slum areas) } \mathrm{n}=700\end{array}$ \\
\hline & Demographic Variables & $53.3(426)$ & $56.8(398)$ \\
\hline 1. & Sex of the respondents (SR) & Male & $44.7(374)$ & $43.2(302)$
\end{tabular}


32 Md. Monirul Islam, Md. Imam Hussain and Md. Shahidul Islam

\begin{tabular}{|c|c|c|c|c|}
\hline & $\chi^{2}$ & & $38.34 * *$ & $56.08 * *$ \\
\hline 2. & $\begin{array}{l}\text { Types of Family (TF) } \\
\chi^{2}\end{array}$ & $\begin{array}{c}\text { Single } \\
\text { Joint }\end{array}$ & $\begin{array}{c}39.2(314) \\
60.8(486) \\
22.47 * *\end{array}$ & $\begin{array}{l}43.1(302) \\
56.9(398) \\
17.59 * * *\end{array}$ \\
\hline 3. & $\begin{array}{l}\text { No. of Family Members } \\
\text { (NFM) } \\
\chi^{2}\end{array}$ & $\begin{array}{l}1-2 \\
3-4 \\
5+\end{array}$ & $\begin{array}{l}27.4(219) \\
31.0(248) \\
41.6(333) \\
112.90^{* * *} \\
\end{array}$ & $\begin{array}{l}25.2(176) \\
31.3(219) \\
43.5(305) \\
91.04 * * *\end{array}$ \\
\hline 4. & $\begin{array}{l}\text { Age of Respondents (in } \\
\text { years) (AR) } \\
\chi^{2}\end{array}$ & $\begin{array}{c}<30 \\
30-40 \\
40-50 \\
50+\end{array}$ & $\begin{array}{l}32.4(259) \\
28.1(225) \\
21.0(168) \\
18.5(148) \\
88.61^{* *}\end{array}$ & $\begin{array}{l}34.3(240) \\
25.1(176) \\
21.6(151) \\
19.0(133) \\
33.75^{* * *}\end{array}$ \\
\hline 5. & $\begin{array}{l}\text { Suffering From Diseases } \\
\text { Due to Drugs (SD) } \\
\chi^{2}\end{array}$ & $\begin{array}{l}\text { Yes } \\
\text { No }\end{array}$ & $\begin{array}{l}81.3(650) \\
18.7(150) \\
12.57 * * *\end{array}$ & $\begin{array}{l}77.1(540) \\
22.9(160) \\
19.11^{* * * * *}\end{array}$ \\
\hline 6. & $\begin{array}{l}\text { Types of Diseases Due to } \\
\text { Drugs (TDD) } \\
\chi^{2}\end{array}$ & $\begin{array}{c}\text { Pain in Liver } \\
\text { Hepatitis } \\
\text { Dyspepsia } \\
\text { Declining Sexual Ability } \\
\text { Vomiting } \\
\text { Others }\end{array}$ & $\begin{array}{l}21.7(174) \\
12.2(98) \\
37.0(296) \\
18.3(146) \\
4.3(34) \\
6.5(52) \\
112.98^{* *}\end{array}$ & $\begin{array}{c}18.6(130) \\
11.3(80) \\
32.3(226) \\
17.0(119) \\
8.2(57) \\
12.6(88) \\
131.44 * * *\end{array}$ \\
\hline 7. & $\begin{array}{l}\text { Habit of Smoking (HS) } \\
\chi^{2}\end{array}$ & $\begin{array}{l}\text { Yes } \\
\text { No }\end{array}$ & $\begin{array}{l}78.2(626) \\
21.8(174) \\
17.19 * * * \\
\end{array}$ & $\begin{array}{l}81.5(571) \\
18.5(129) \\
27.33^{* * *}\end{array}$ \\
\hline & \multicolumn{4}{|l|}{ Socio-economic Variables } \\
\hline 1. & $\begin{array}{l}\text { Religion (REL) } \\
\chi^{2}\end{array}$ & $\begin{array}{c}\text { Muslim } \\
\text { Non-Muslim }\end{array}$ & $\begin{array}{l}38.2(306) \\
61.8(494) \\
36.21^{*}\end{array}$ & $\begin{array}{l}31.6(221) \\
68.4(479) \\
25.19^{* *}\end{array}$ \\
\hline 2. & $\begin{array}{l}\text { Educational Qualifications } \\
\text { (EQ) } \\
\chi^{2}\end{array}$ & $\begin{array}{c}\text { Illiterate } \\
\text { Primary } \\
\text { Secondary } \\
\text { Higher secondary and above }\end{array}$ & $\begin{array}{l}36.1(288) \\
29.7(238) \\
18.0(144) \\
16.2(130) \\
116.93 * * *\end{array}$ & $\begin{array}{l}15.5(108) \\
17.1(120) \\
18.4(129) \\
49.0(343) \\
98.52 * * * *\end{array}$ \\
\hline 3. & $\begin{array}{l}\text { Knowledge About Drugs } \\
\text { (KAD) } \\
\chi^{2}\end{array}$ & $\begin{array}{l}\text { Yes } \\
\text { No }\end{array}$ & $\begin{array}{l}79.5(636) \\
20.5(164) \\
22.87 * *\end{array}$ & $\begin{array}{l}92.4(647) \\
7.6(53) \\
18.91^{* *}\end{array}$ \\
\hline 4. & $\begin{array}{l}\text { Economic Status (ES) } \\
\chi^{2}\end{array}$ & $\begin{array}{l}\text { Low } \\
\text { Medium } \\
\text { High }\end{array}$ & $\begin{array}{c}38.2(306) \\
33.5(268) \\
28.3(226) \\
54.22 * *\end{array}$ & $\begin{array}{l}41.6(291) \\
32.4(227) \\
26.0(182) \\
29.67 * * *\end{array}$ \\
\hline \multicolumn{5}{|c|}{ Continued Table 2.} \\
\hline $\begin{array}{l}\text { Serial } \\
\text { Nos. }\end{array}$ & Variables & Categories & $\begin{array}{c}\text { Percentage (Slum } \\
\text { areas) } n=800\end{array}$ & $\begin{array}{l}\text { Percentage (Non- } \\
\text { slum areas) } n=700\end{array}$ \\
\hline & Socio-economic Variables & & & \\
\hline 5. & $\begin{array}{l}\text { Occupation of the } \\
\text { Respondents (OR) } \\
\chi^{2}\end{array}$ & $\begin{array}{c}\text { Businessman } \\
\text { Service Holder } \\
\text { Day Labors/ Rickshaw puller } \\
\text { Unemployed }\end{array}$ & $\begin{array}{c}27.6(221) \\
11.3(90) \\
28.1(225) \\
33.0(264) \\
119.02 * *\end{array}$ & $\begin{array}{l}32.7(229) \\
22.3(156) \\
--- \\
45.0(315) \\
88.51 * * * \\
\end{array}$ \\
\hline
\end{tabular}


Determinants of Drug Addiction in Slum and Non-slum Areas of Chittagong, Bangladesh 33

\begin{tabular}{|c|c|c|c|c|}
\hline 6. & $\begin{array}{l}\text { Duration of Taking Drugs } \\
\text { (DTD) } \\
\chi^{2}\end{array}$ & $\begin{array}{c}\text { Not Addict } \\
4 \text { Years and Less } \\
5 \text { Years and Above }\end{array}$ & $\begin{array}{c}65.2(521) \\
24.6(197) \\
10.2(82) \\
28.67 * * * \\
\end{array}$ & $\begin{array}{l}61.4(430) \\
20.2(141) \\
18.4(129) \\
51.56^{* * * *} \\
\end{array}$ \\
\hline 7. & $\begin{array}{l}\text { Watching T.V./LCD (WT) } \\
\chi^{2}\end{array}$ & $\begin{array}{l}\text { Yes } \\
\text { No }\end{array}$ & $\begin{array}{c}36.4(291) \\
63.6(509) \\
12.98 * *\end{array}$ & $\begin{array}{l}28.2(197) \\
71.8(503) \\
34.61 * * *\end{array}$ \\
\hline 8. & $\begin{array}{l}\text { Reading News Paper/ } \\
\text { Magazine(R EAD) } \\
\chi^{2}\end{array}$ & $\begin{array}{l}\text { Yes } \\
\text { No }\end{array}$ & $\begin{array}{l}34.0(272) \\
66.0(528) \\
33.74 * * *\end{array}$ & $\begin{array}{l}31.5(221) \\
68.5(479) \\
21.98^{* * *}\end{array}$ \\
\hline 9. & $\begin{array}{l}\text { Knowledge About the } \\
\text { Harmful Effect of Drugs } \\
\text { (KAHD) } \\
\chi^{2}\end{array}$ & $\begin{array}{l}\text { Yes } \\
\text { No }\end{array}$ & $\begin{array}{l}87.5(700) \\
12.5(100) \\
10.98 * *\end{array}$ & $\begin{array}{c}91.4(640) \\
8.6(60) \\
\\
17.55^{* * *}\end{array}$ \\
\hline 10. & $\begin{array}{l}\text { Type of Drugs (TD) } \\
\chi^{2}\end{array}$ & $\begin{array}{c}\text { Heroin } \\
\text { Phensidyl } \\
\text { Cannabis } \\
\text { Wine } \\
\text { Tablet } \\
\text { Pethedrine }\end{array}$ & $\begin{array}{c}16.2(130) \\
22.0(175) \\
28.1(225) \\
19.3(154) \\
6.2(50) \\
8.2(66) \\
77.14 * * *\end{array}$ & $\begin{array}{c}29.0(203) \\
24.2(169) \\
31.6(221) \\
4.0(28) \\
4.1(29) \\
7.1(50) \\
109.16^{* * *}\end{array}$ \\
\hline 11. & $\begin{array}{l}\text { Causes Behind Taking } \\
\text { Drugs (CBTD) } \\
\chi^{2}\end{array}$ & $\begin{array}{c}\text { Frustration } \\
\text { Close Contact with Friends } \\
\text { Inquisitively } \\
\text { Conflict between Parents } \\
\text { Couple Conflict } \\
\text { Failure in Love }\end{array}$ & $\begin{array}{c}5.0(40) \\
32.4(260) \\
12.5(100) \\
13.8(110) \\
27.5(220) \\
8.8(70) \\
69.77 * * *\end{array}$ & $\begin{array}{c}11.2(78) \\
20.7(145) \\
10.0(70) \\
14.0(98) \\
31.5(221) \\
12.6(88) \\
103.26^{* * * *}\end{array}$ \\
\hline 12. & $\chi^{2}$ & $\begin{array}{c}\text { Railway Stations (old) } \\
\text { Akber Shah Mazar } \\
\text { Barma Colony } \\
\text { Kasai Para } \\
\text { Port connecting Road (Hali Shahar) } \\
\text { Madar Bari } \\
\text { Debar Par } \\
\text { Firoz Shah Lane } \\
\text { Baklia } \\
\text { Bohaddar Hat } \\
\text { Others }\end{array}$ & $\begin{array}{c}16.3(130) \\
12.5(100) \\
8.8(70) \\
5.0(40) \\
12.5(100) \\
10.0(80) \\
3.7(30) \\
5.0(40) \\
7.5(60) \\
11.2(90) \\
7.5(60) \\
79.29 * *\end{array}$ & $\begin{array}{c}7.0(49) \\
11.2(78) \\
3.7(26) \\
4.6(32) \\
14.2(99) \\
8.5(60) \\
10.1(71) \\
15.8(111) \\
6.0(42) \\
12.7(89) \\
6.2(43) \\
134.52 * * *\end{array}$ \\
\hline 13. & $\begin{array}{l}\text { Tendency to Comeback } \\
\text { from drugs (TCD) } \\
\chi^{2}\end{array}$ & $\begin{array}{l}\text { Yes } \\
\text { No }\end{array}$ & $\begin{array}{l}87.5(700) \\
12.5(100) \\
27.48^{* * *}\end{array}$ & $\begin{array}{c}76.9(538) \\
23.1(162) \\
19.67 * * *\end{array}$ \\
\hline
\end{tabular}

Note: Figures within parentheses indicate number of respondents.

Table 3. Logistic regression estimates of drug addiction according to the selected demographic and socio-economic variables in slum areas of Chittagong metropolitan city in Bangladesh.

\begin{tabular}{|l|c|c|c|c|}
\hline Selected Variables & $\begin{array}{l}\text { Regression Coefficients } \\
(\beta)\end{array}$ & Standard Errors & Significant Level \\
$\left(\mathrm{e}^{\beta}\right)$
\end{tabular}


34 Md. Monirul Islam, Md. Imam Hussain and Md. Shahidul Islam

\begin{tabular}{|c|c|c|c|c|}
\hline b) Joint & $0.7112^{* * * *}$ & 0.0125 & 0.4135 & 2.0364 \\
\hline $\begin{array}{llc}N F M & \text { a) } & 1-2 \\
& \text { b) } & 3-4 \\
& \text { c) } & 5+\end{array}$ & $\begin{array}{c}---- \\
0.8135^{* *} \\
0.8446^{* * *}\end{array}$ & $\begin{array}{c}---- \\
0.0024 \\
0.0051\end{array}$ & $\begin{array}{c}--- \\
0.2215 \\
0.3231\end{array}$ & $\begin{array}{l}1.0000 \\
2.2558 \\
2.3270\end{array}$ \\
\hline $\begin{array}{ll}A R & \text { a) }<30 \\
& \text { b) } 30-40 \\
& \text { c) } 40-50 \\
& \text { d) } 50+\end{array}$ & $\begin{array}{c}---- \\
-0.1825 \\
-0.1940 \\
-0.4132\end{array}$ & $\begin{array}{l}---- \\
0.1430 \\
0.2271 \\
0.1160\end{array}$ & $\begin{array}{l}---- \\
0.0025 \\
0.0135 \\
0.0021\end{array}$ & $\begin{array}{l}1.0000 \\
0.8332 \\
0.8237 \\
0.6615\end{array}$ \\
\hline $\begin{array}{r}S D \text { a) Yes } \\
\text { b) No }\end{array}$ & $\begin{array}{l}---- \\
-0.6913 \\
\end{array}$ & $\begin{array}{c}---- \\
0.0014 \\
\end{array}$ & $\begin{array}{c}---- \\
0.0005 \\
\end{array}$ & $\begin{array}{l}1.0000 \\
0.5009\end{array}$ \\
\hline $\begin{array}{l}T D D \text { a) Pain in Liver } \\
\text { b) Hepatitis } \\
\text { c) Dyspepsia } \\
\text { d) Declining } \\
\text { Sexual Ability } \\
\text { e) Vomiting } \\
\text { f) Others }\end{array}$ & $\begin{array}{c}---- \\
-0.2493^{*} \\
-0.3127 * * * \\
-0.4492^{*} \\
\\
-0.5214 * * \\
-0.6015 \\
\end{array}$ & $\begin{array}{l}0.2346 \\
0.1580 \\
0.2610 \\
\\
0.1751 \\
0.2213 \\
\end{array}$ & $\begin{array}{l}---- \\
0.0125 \\
0.0854 \\
0.1760 \\
\\
0.0257 \\
0.0934 \\
\end{array}$ & $\begin{array}{l}1.0000 \\
0.7793 \\
0.7315 \\
0.6381\end{array}$ \\
\hline $\begin{array}{r}H S \text { a) Yes } \\
\text { b) No }\end{array}$ & $\begin{array}{c}---- \\
1.0253 * *\end{array}$ & $\begin{array}{c}---- \\
0.3149 \\
\end{array}$ & $\begin{array}{c}--- \\
0.2861 \\
\end{array}$ & $\begin{array}{l}1.0000 \\
2.7879 \\
\end{array}$ \\
\hline \multicolumn{5}{|l|}{ Socio-economic variables } \\
\hline $\begin{array}{l}R E L \text { a) Muslim } \\
\text { b) Non-Muslim }\end{array}$ & $\begin{array}{c}---- \\
1.07182^{* * * * *} \\
\end{array}$ & $\begin{array}{c}--- \\
0.0021 \\
\end{array}$ & $\begin{array}{c}--- \\
0.1830 \\
\end{array}$ & $\begin{array}{l}1.0000 \\
2.9207 \\
\end{array}$ \\
\hline $\begin{array}{l}E Q \text { a) Illiterate } \\
\text { b) Primary } \\
\text { c) Secondary } \\
\text { d) Higher Secondary } \\
\text { and Above } \\
\end{array}$ & $\begin{array}{l}---- \\
0.0564 \\
1.0273 \\
1.0695\end{array}$ & $\begin{array}{l}---- \\
0.1328 \\
0.0002 \\
0.0314\end{array}$ & $\begin{array}{c}---- \\
0.1439 \\
0.1812 \\
0.2516\end{array}$ & $\begin{array}{l}1.0000 \\
0.9820 \\
2.7935 \\
2.8920\end{array}$ \\
\hline $\begin{array}{c}K A D \text { a) Yes } \\
\text { b) No }\end{array}$ & $\begin{array}{c}---- \\
1.0824 * * *\end{array}$ & $\begin{array}{c}---- \\
0.0090\end{array}$ & $\begin{array}{c}---- \\
0.0071 \\
\end{array}$ & $\begin{array}{l}1.0000 \\
2.9518 \\
\end{array}$ \\
\hline $\begin{array}{l}\text { ES a) Low } \\
\text { b) Medium } \\
\text { c) High }\end{array}$ & $\begin{array}{c}------ \\
0.1132 \\
1.0914 * * * *\end{array}$ & $\begin{array}{l}---- \\
0.0125 \\
0.0218\end{array}$ & $\begin{array}{l}----- \\
0.0010 \\
0.0017\end{array}$ & $\begin{array}{l}1.0000 \\
0.8930 \\
2.9784\end{array}$ \\
\hline $\begin{array}{l}O R \text { a) Businessman } \\
\text { b) Service holders } \\
\text { c) Day labors/ } \\
\text { Rickshaw puller } \\
\text { d) Unemployed }\end{array}$ & $\begin{array}{c}---- \\
0.4132^{*} \\
0.6527 * * \\
1.1892 * *\end{array}$ & $\begin{array}{l}---- \\
0.0318 \\
0.0056 \\
0.0020\end{array}$ & $\begin{array}{l}---- \\
0.0125 \\
0.0340 \\
0.0045\end{array}$ & $\begin{array}{l}1.0000 \\
1.5116 \\
2.4368 \\
\\
3.2845\end{array}$ \\
\hline $\begin{array}{l}\text { DTD a) Not addict } \\
\text { b) } 4 \text { years and less } \\
\text { c) } 5 \text { years and above }\end{array}$ & $\begin{array}{c}--- \\
1.2417^{* * * *} \\
1.6210^{* * * *}\end{array}$ & $\begin{array}{c}---- \\
0.1135 \\
0.0153 \\
\end{array}$ & $\begin{array}{c}---- \\
0.1430 \\
0.2214 \\
\end{array}$ & $\begin{array}{l}1.0000 \\
3.4615 \\
5.0581\end{array}$ \\
\hline $\begin{array}{l}W T \text { a) Yes } \\
\text { b) No }\end{array}$ & $0.8812 * *$ & $\begin{array}{c}---- \\
0.0314\end{array}$ & $\begin{array}{c}---- \\
0.0120\end{array}$ & $\begin{array}{l}1.0000 \\
2.4138\end{array}$ \\
\hline
\end{tabular}

Continued Table 3.

\begin{tabular}{|c|c|c|c|c|}
\hline Selected Variables & $\begin{array}{c}\text { Regression Coefficients } \\
(\beta)\end{array}$ & Standard Errors & $\begin{array}{c}\text { Significant Level } \\
\text { Odds Ratios } \\
\left(\mathrm{e}^{\beta}\right)\end{array}$ \\
\hline Socio-economic variables & \multicolumn{3}{|c|}{} \\
\hline READ a) Yes & ---- & ---- & --- & 1.0000 \\
b) No & $0.7152^{* * *}$ & 0.0181 & 0.1725 & 2.0446 \\
\hline$K A H D$ a) Yes & --- & --- & 1.0000 \\
b) No & $0.9854^{* * * *}$ & 0.1450 & 0.0120 & 2.6789 \\
\hline$T D$ a) Heroin & --- & ---- & --- & 1.0000 \\
b) Phensidyl & 0.8831 & 0.0942 & 0.0097 & 2.4184 \\
c) Cannabis & 0.6412 & 0.2492 & 0.1135 & 1.8988 \\
\hline
\end{tabular}


Determinants of Drug Addiction in Slum and Non-slum Areas of Chittagong, Bangladesh 35

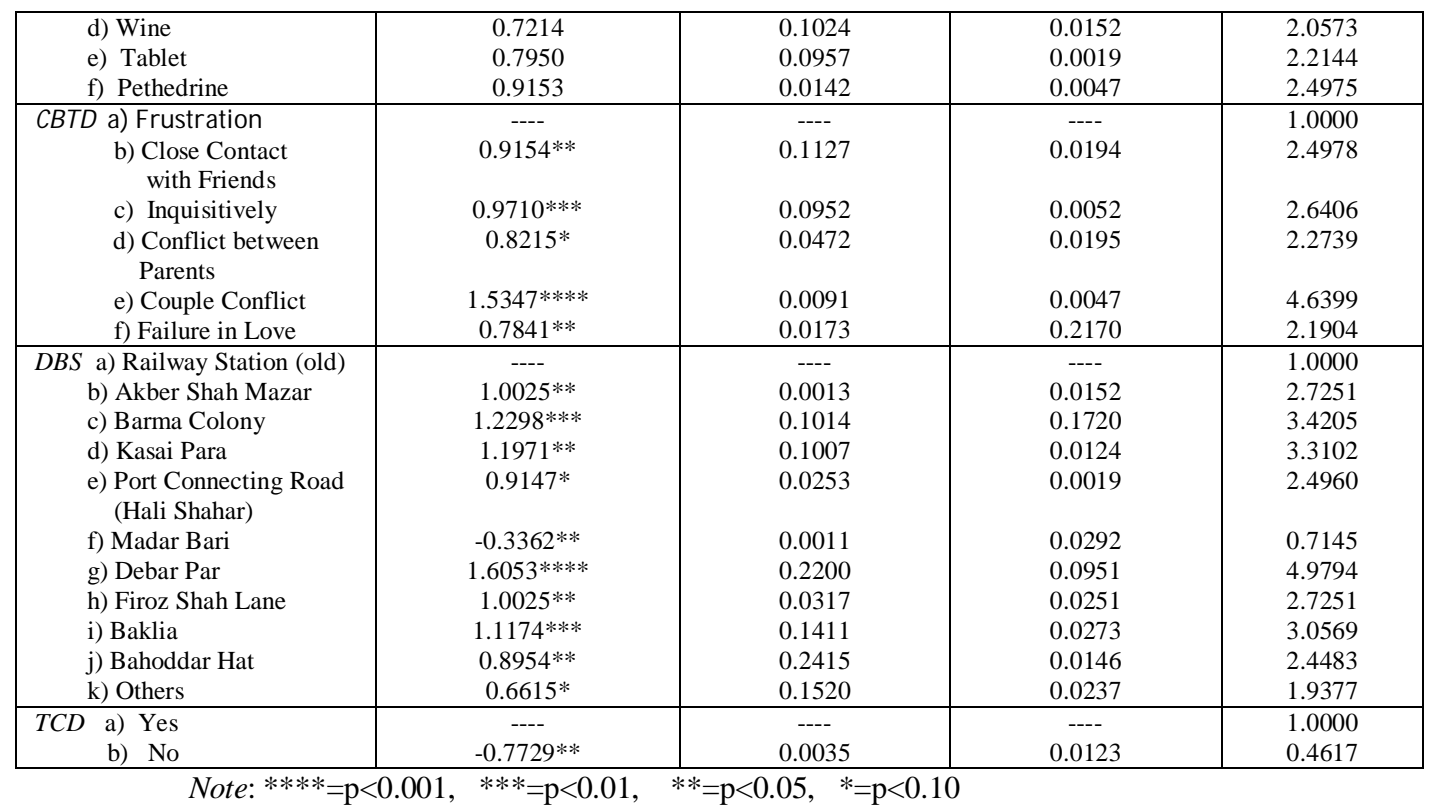

Table 4. Logistic regression estimates of drug addiction according to the selected socio-economic and demographic variables in non-slum areas of Chittagong metropolitan city in Bangladesh.

\begin{tabular}{|c|c|c|c|c|}
\hline Selected variables & $\begin{array}{l}\text { Regression } \\
\text { coefficients }\end{array}$ & Standard error & Significant level & Odds ratios \\
\hline \multicolumn{5}{|c|}{ Demographic variables } \\
\hline $\begin{array}{ll}S R & \text { a) Male } \\
& \text { b) Female }\end{array}$ & $\begin{array}{c}---- \\
-0.2281 * * * *\end{array}$ & $\begin{array}{c}--- \\
0.1048\end{array}$ & $\begin{array}{c}---- \\
0.0241\end{array}$ & $\begin{array}{l}1.0000 \\
0.7960\end{array}$ \\
\hline $\begin{array}{ll}T F & \text { a) Single } \\
& \text { b) Joint }\end{array}$ & $\begin{array}{c}---- \\
0.1371\end{array}$ & $\begin{array}{c}---- \\
0.2831\end{array}$ & $\begin{array}{c}---- \\
0.1061\end{array}$ & $\begin{array}{l}1.0000 \\
1.1469\end{array}$ \\
\hline $\begin{array}{llc}N F M & \text { a) } & 1-2 \\
& \text { d) } & 3-4\end{array}$ & $\begin{array}{c}----- \\
0.3485^{* *}\end{array}$ & $\begin{array}{c}---- \\
0.3250\end{array}$ & $\begin{array}{c}---- \\
0.3162\end{array}$ & $\begin{array}{l}1.0000 \\
1.4169\end{array}$ \\
\hline
\end{tabular}


Md. Monirul Islam, Md. Imam Hussain and Md. Shahidul Islam

\begin{tabular}{|c|c|c|c|c|}
\hline e) $5+$ & $1.0269 * * *$ & 0.1186 & 0.1152 & 2.7924 \\
\hline $\begin{array}{ll}A R & \text { a) }<30 \\
\text { b) } 30-40 \\
\text { c) } 40-50 \\
\text { d) } 50+\end{array}$ & $\begin{array}{c}---- \\
0.6539 \\
0.9852 \\
-0.6438 \\
\end{array}$ & $\begin{array}{l}---- \\
0.0641 \\
0.0237 \\
0.0074\end{array}$ & $\begin{array}{l}--- \\
0.2163 \\
0.1974 \\
0.9841\end{array}$ & $\begin{array}{l}1.0000 \\
0.9845 \\
0.8036 \\
0.3467\end{array}$ \\
\hline $\begin{array}{ll}S D & \text { a) Yes } \\
& \text { b) No }\end{array}$ & $\begin{array}{c}---- \\
1.3150 * * * *\end{array}$ & $\begin{array}{c}---- \\
0.0218\end{array}$ & $\begin{array}{c}---- \\
0.0025\end{array}$ & $\begin{array}{l}1.0000 \\
3.7248\end{array}$ \\
\hline $\begin{array}{l}\text { TDD a) Pain in Liver } \\
\text { b) Hepatitis } \\
\text { c) Dyspepsia } \\
\text { d) Declining Sexual Ability } \\
\text { e) Vomiting } \\
\text { f) Others }\end{array}$ & $\begin{array}{c}--- \\
-0.8175^{*} * \\
-0.6710 * \\
-0.7175^{*} * \\
-0.6188^{*} * * * \\
-0.7819 * * \\
\end{array}$ & $\begin{array}{l}--- \\
0.1830 \\
0.1103 \\
0.2140 \\
0.1080 \\
0.2019\end{array}$ & $\begin{array}{l}--- \\
0.0945 \\
0.0742 \\
0.0418 \\
0.0649 \\
0.0457\end{array}$ & $\begin{array}{l}1.0000 \\
0.4415 \\
0.5112 \\
0.4880 \\
0.5386 \\
0.4575\end{array}$ \\
\hline $\begin{array}{ll}H S & \text { a) Yes } \\
& \text { b) No }\end{array}$ & $\begin{array}{l}---- \\
1.5781\end{array}$ & 0.0015 & $\begin{array}{l}---- \\
0.0180\end{array}$ & $\begin{array}{l}1.0000 \\
4.8457\end{array}$ \\
\hline \multicolumn{5}{|l|}{ Socio-economic Variables } \\
\hline $\begin{array}{l}R E L \text { a) Muslim } \\
\text { b) Non-Muslim }\end{array}$ & $\begin{array}{c}---- \\
0.4357 * * *\end{array}$ & 0.0215 & 0.2431 & $\begin{array}{l}1.0000 \\
1.5460 \\
\end{array}$ \\
\hline $\begin{array}{l}E Q \text { a) Illiterate } \\
\text { b) Primary } \\
\text { c) Secondary } \\
\text { d) Higher Secondary } \\
\text { and Above } \\
\end{array}$ & $\begin{array}{c}---- \\
1.4240 * * \\
0.3164 * \\
1.0277 * *\end{array}$ & $\begin{array}{l}---- \\
0.1029 \\
0.0158 \\
0.0561\end{array}$ & $\begin{array}{c}--- \\
0.0031 \\
0.2283 \\
0.3105\end{array}$ & $\begin{array}{l}1.0000 \\
0.1169 \\
3.4217 \\
2.7946\end{array}$ \\
\hline $\begin{aligned} & K A D \text { a) Yes } \\
& \text { b) No } \\
&\end{aligned}$ & $1.0053^{*--}$ & $\begin{array}{c}--- \\
0.2982 \\
\end{array}$ & $\begin{array}{c}----- \\
0.1163\end{array}$ & $\begin{array}{l}1.0000 \\
2.7327 \\
\end{array}$ \\
\hline $\begin{array}{l}\text { ES a) Low } \\
\text { b) Medium } \\
\text { c) High }\end{array}$ & $\begin{array}{c}--- \\
1.3125^{* *} \\
1.0146^{* *} \\
\end{array}$ & $\begin{array}{c}---- \\
0.4135 \\
0.2231\end{array}$ & $\begin{array}{l}--- \\
0.1127 \\
0.1893 \\
\end{array}$ & $\begin{array}{l}1.0000 \\
3.7155 \\
2.7583 \\
\end{array}$ \\
\hline $\begin{array}{l}\text { OR a) Businessman } \\
\text { b) Service holders } \\
\text { c) Unemployed } \\
\end{array}$ & $\begin{array}{c}---- \\
0.9251 \\
1.4382 * * * \\
\end{array}$ & $\begin{array}{l}---- \\
0.0150 \\
0.1968\end{array}$ & $\begin{array}{c}-\overline{---} \\
0.0028 \\
0.3321\end{array}$ & $\begin{array}{l}1.0000 \\
2.5221 \\
4.2131 \\
\end{array}$ \\
\hline $\begin{array}{l}D T D \text { a) Not addict } \\
\text { b) } 4 \text { years and less } \\
\text { c) } 5 \text { years and above }\end{array}$ & $\begin{array}{c}----- \\
-0.0958-0.0865\end{array}$ & $\begin{array}{c}--- \\
0.0120 \\
0.0964\end{array}$ & $\begin{array}{c}---- \\
0.0053 \\
0.0650\end{array}$ & $\begin{array}{l}1.0000 \\
0.9086 \\
0.8852 \\
\end{array}$ \\
\hline $\begin{array}{l}W T \text { a) Yes } \\
\text { b) No }\end{array}$ & $\begin{array}{c}--- \\
0.9468 * *\end{array}$ & $\begin{array}{c}---- \\
0.2160\end{array}$ & $\begin{array}{c}---- \\
0.1102\end{array}$ & $\begin{array}{l}1.0000 \\
2.5774\end{array}$ \\
\hline $\begin{array}{r}R E A D \text { a) Yes } \\
\text { b) No }\end{array}$ & $0.9870 * *$ & 0.0295 & 0.2851 & $\begin{array}{l}1.0000 \\
2.6832 \\
\end{array}$ \\
\hline
\end{tabular}

Continued Table 4 .

\begin{tabular}{|c|c|c|c|c|}
\hline Selected variables & $\begin{array}{l}\text { Regression } \\
\text { coefficients }\end{array}$ & Standard error & Significant level & Odds ratios \\
\hline \multicolumn{5}{|c|}{ Socio-economic Variables } \\
\hline $\begin{array}{r}K A H D \text { a) Yes } \\
\text { b) No }\end{array}$ & $\begin{array}{c}--- \\
1.0025^{*} * *\end{array}$ & $\begin{array}{c}--- \\
0.0073\end{array}$ & $\begin{array}{c}--- \\
0.0151\end{array}$ & $\begin{array}{l}1.0000 \\
2.7251 \\
\end{array}$ \\
\hline $\begin{array}{l}\text { TD a) Heroin } \\
\text { b) Phensidyl } \\
\text { c) Cannabis } \\
\text { d) Wine } \\
\text { e) Tablet } \\
\text { f) Pethedine }\end{array}$ & $\begin{array}{c}--- \\
1.5311^{* *} \\
0.7024 \\
1.3952^{* * *} * \\
0.5053 \\
1.4830^{* * *}\end{array}$ & $\begin{array}{l}---- \\
0.0150 \\
0.4315 \\
0.0047 \\
0.1200 \\
0.0142\end{array}$ & $\begin{array}{c}--- \\
0.0031 \\
0.0527 \\
0.0014 \\
0.0934 \\
0.0065\end{array}$ & $\begin{array}{l}1.0000 \\
4.6233 \\
2.0186 \\
4.0358 \\
1.6575 \\
4.4061\end{array}$ \\
\hline
\end{tabular}




\begin{tabular}{|c|c|c|c|c|}
\hline $\begin{array}{l}\text { CBTD a) Frustration } \\
\text { b) Close Contact with } \\
\text { Friends } \\
\text { c) Inquisitively } \\
\text { d) Conflict between } \\
\text { Parents } \\
\text { e) Couple Conflict } \\
\text { f) Failure in Love }\end{array}$ & $\begin{array}{c}-\overline{---} \\
0.8725^{*} \\
1.0012 * * \\
1.0019 * * \\
1.4137 * * * \\
1.6148^{* *}\end{array}$ & $\begin{array}{l}-\overline{---} \\
0.3127 \\
0.0041 \\
0.0069 \\
\\
0.0107 \\
0.0039 \\
\end{array}$ & $\begin{array}{l}-\overline{--} \\
0.2218 \\
0.0410 \\
0.0345 \\
0.0050 \\
0.0100\end{array}$ & $\begin{array}{l}1.0000 \\
2.3929 \\
2.7215 \\
2.7235 \\
4.1111 \\
5.0269 \\
\end{array}$ \\
\hline $\begin{array}{l}\text { a) Railway Station (old) } \\
\text { b) Akber Shah Mazar } \\
\text { c) Barma Colony } \\
\text { d) Kasai Para } \\
\text { e) Port Connecting Road } \\
\text { (Hali Shahar) } \\
\text { f) Madar Bari } \\
\text { g) Debar Par } \\
\text { h) Firoz Shah Lane } \\
\text { i) Bakalia } \\
\text { j) Bahoddar Hat } \\
\text { k) Others }\end{array}$ & $\begin{array}{c}--- \\
1.4130 * * \\
0.9714 * \\
1.1531 * * * \\
1.2272 * * * \\
\\
0.9830 * * \\
1.5125 * * * \\
1.3371 * * * \\
0.8122 * \\
0.7433 * \\
0.9317 * * \\
\end{array}$ & $\begin{array}{l}--- \\
0.0097 \\
0.0138 \\
0.0068 \\
0.0120 \\
\\
0.2251 \\
0.0149 \\
0.0042 \\
0.0250 \\
0.0630 \\
0.0205 \\
\end{array}$ & $\begin{array}{c}--- \\
0.2307 \\
0.0529 \\
0.0427 \\
0.0022 \\
0.0359 \\
0.0240 \\
0.0260 \\
0.3100 \\
0.0941 \\
0.0842 \\
\end{array}$ & $\begin{array}{l}1.0000 \\
4.1083 \\
2.6416 \\
3.1680 \\
3.4117 \\
2.6725 \\
4.5381 \\
3.8080 \\
2.2529 \\
2.1029 \\
2.5388 \\
\end{array}$ \\
\hline $\begin{array}{cc}T C D \text { a) Yes } \\
\\
\text { b) No }\end{array}$ & $\begin{array}{c}---- \\
1.2371^{* * *}\end{array}$ & $\begin{array}{c}---- \\
0.0017\end{array}$ & $\begin{array}{c}---- \\
0.0943\end{array}$ & $\begin{array}{l}1.0000 \\
3.4456\end{array}$ \\
\hline
\end{tabular}

\section{References}

[1] Department of Narcotics Control, Annual Drug Report of Bangladesh, Ministry of Home Affairs, Government of the People's Republic of Bangladesh, 2013, 13.

[2] Bangladesh Bureau of Statistics (BBS), Population and Housing Census2011, 2014, $2,8$.

[3] M. Sharma, K.Z. Rahman and R. Kelly: Reducing the demand for drugs and preventing HIV in Bangladesh: A partnership between law enforcement, the community and treatment agencies. Department of Narcotics Control, Dhaka, Bangladesh, 2006, 145.

[4] K. Ford and A.Nag, Demography 1980, 18(1), 88.

[5] M. H. Chowdhury and J. Gupta, Social Biology, 1998, 21, 131.

[6] A. Ahmad and B. Rahman, The Journal of Family Welfare, 1984, XXX(1), 
38 Md. Monirul Islam, Md. Imam Hussain and Md. Shahidul Islam

84.

[7] Drugs Control Department, Divisional Office, Chittagong, Ministry of Home Affairs, Government of the People's Republic of Bangladesh, 2014.

Manuscript received on 20 September, 2018, Revised manuscript received on 20 March, 2019 and accepted on 21 March, 2019

The Chittagong Univ. J. Sc. Vol. 41(1), 2019 